\title{
The Auschwitz Trilogy by Primo Levi: Language as a Form of Survival
}

\author{
Carmen F. Blanco Valdés
}

Department of Language Sciences, Faculty of Philosophy and Literature, University of Cordoba, Spain

Copyright $\bigcirc 2016$ by authors, all rights reserved. Authors agree that this article remains permanently open access under the terms of the Creative Commons Attribution License 4.0 International License

\begin{abstract}
The three memorial works written by Primo Levi about the experiences lived during his stay at Auschwitz concentration camp and his subsequent memories about it, If This is a Man, The Truce and The Drowned and the Saved, known as Auschwitz Trilogy, have several elements in common. We think that one has not been delved into deeply: the purpose of pragmatic mechanisms of the communication process. The main aim of this article is to investigate this issue in order to prove that the communication process is conceived as a basic element not only of survival (a commonly defended idea) but also - and above all - of a reconstruction of the human entity. To that extent, verbs such as comunicare (communicating) and capire (understanding) achieve a polysemic condition and can be interpreted from a double perspective. On one side, individual communication / understanding, in which verbs act in their straight sense speaking in order to understand and being understood helps getting out of chaos -. On the other side, choral communication / understanding, in which the reader is put in an alterity perspective and in which communication transcends the pure communicative act to transform the message into a universal discourse.
\end{abstract}

Keywords Primo Levi, Auschwitz, Language, Pragmatic Communication

\section{Introduction}

Probably, the testimonial novel, Se questo è un uomo ${ }^{1}$ (If This is a Man) [1] by Primo Levi is the most heart-breaking,

\footnotetext{
${ }^{1}$ The novel Se questo è un uomo (SQU) was published in 1947 and had a rather limited circulation (1500 copies) and confined to the Turin area. In 1958 Einaudi published a new edition, but the book was taken more as an educational and political text. It was not until the publication of Levi's Tregua that he was recognized as a great writer: "A partire dal Premio Campiello (settembre 1963) si avviava una sintonia istintiva e profonda tra autore a lettori, sempre più intensa con il passare degli anni”. Vid. Ferrero [8], VIII.
}

realistic, hard and solemn literary account that has ever been written about the events in the extermination camp of Auschwitz ${ }^{2}$ : un nome privo di significato, allora per noi; $m a$ doveva pur corrispondere a un luogo di questa terra (p. 17), writes Levi at the first mention of the destination. Levi narrates events "al limiti dell'indicibile" - writes David Meghangi [2]- and what is surprising is the objectivity -or even distance and detachment from the literary res-, with which the author, sadly the protagonist of this story, presents the facts. Each chapter is a scene, a picture in his personal reconstruction of his memories [3] $]^{3}$.

This reconstructive process continues with the novel $L a$ Tregua ${ }^{4}$ (The Truce) [4], which recounts the author's last moments in the concentration camp after the barbed wire and the months of pilgrimage to Poland and Europe after release and until the final return to Italy, in the case of Levi, or to other European countries, in the case of other prisoners liberated from the concentration camps [5].

The cycle of works about the author's experiences in the Lager [6] concludes with the essay, published a year before his death, I sommersi e $i$ salvati ${ }^{5}$ (The Drowned and the Saved) [7], which, in his own words: contiene più

\footnotetext{
${ }^{2}$ In July 1943 the Fascist government falls and Mussolini is arrested. On 8 September the armistice was announced. German armed forces occupy Northern and Central Italy. Levi joins a group of partisans, operating in Val d'Aosta, but on the morning of 3 December he was arrested along with two colleagues and sent to the Carpi-Fossoli concentration camp: "I fascisti non ci trattavano male, ci lasciavano scrivere, lasciavano che ci arrivassero i pacchi, ci giuravano sulla loro "fede fascista" che ci avrebbero tenuti là fino alla fine della guerra". However, in February 1944, the Germans took over the Fossoli camp. Levi, together with the other prisoners, among them many women, elderly and children, were sent to Auschwitz on a trip that lasted five days. Vid. Ferrero [2].

${ }_{3}$ In discussions with Bravo and Jalla, Levi commented on the issue of memory: "Avevo un quaderno, ma questi appunti non erano più di venti righe. Avevo troppa paura. Era pericolosissimo scrivere. Il fatto stesso di scrivere era sospetto [...] Non c'era modo di conservare nulla, se non nella memoria".

4 The novel La Tregua (LT) was also published by Einaudi in 1963 and met with rave reviews. He was nominated for the Strega Prize that year and in September was awarded the first edition of what would become the prestigious Campiello prize. These events particularly helped the fortunes of his previous novel which, since that time, was republished on numerous occasions.

${ }_{5}^{5}$ The novel I sommersi e $i$ salvati (ISS), was published in 1986, also by Einaudi, a year before the death of the author, and today can be read as the true spiritual testament of Primo Levi.
} 
considerazioni che ricordi, si sofferma più volentieri sullo stato delle cose qual è oggi che non sulla cronaca retroattiva (p. 23).

As Levi said in many interviews [8], one of the main functions of language -and writing- is communication. In his opinion, there are books one writes to be able to go on living, and this is the only way to achieve vital harmony: language has the power to transform reality. Although the literary devices may not be sufficient to describe the cruelty of the Holocaust, Levi wants to leave a testimonial so that the World is able to understand and also because -from a personal point of view- words have the cathartic power of giving sense to his existence. In fact, one of the fundamental ideas of Levi, is that the lack of communication implies chaos. Writing (communicating) to bring order to chaos is one of the reasons the author gives in order to justify his need to write: "Scrivere è un modo per mettere ordine nel gran caos del mondo" [9].

This is the primary function of the communication process: writing is a way to get rid of chaos, obsessions and fears - as individuals; but, at the same time, from the standpoint of alterity, it is a way to communicate with the others, so that the other can know and understand. This duality can be found in the three works. Writing / Communicating and Knowing / Understanding are the bases of the communication process. As a consequence of this, in the particular world narrated by Levi they become polysemic words both of survival and of vital restoration - from the perspective of individuality-, but also of survival and moral reconstruction - from the perspective of alterity.

Words stand as a symbol of salvation because through them the past and the present can be connected -in order to make memories live- and also freedom can be imagined as a frontier of hope. From the alterity perspective Words are a symbol of salvation as well, because through them one can be understood by the others, in a pragmatical sense ${ }^{6}$.

\section{Methodology}

Based on these considerations, beyond the various atrocities related in If This is a Man and the difficulties in rebuilding the human identity mentioned in The Truce, beyond any historical or pedagogical reading, answers to our questions can be found in the pages of our author's works and, in this paper, our aim is to analyse the pragmatic functionality of the communication process, both from one's own individual perspective and the others' perspective.

The first question is how the writer Primo Levi faces the narrative of the whole oral communication process and how he reflects it in written form in the two novels: the communication process, on the lived and recounted circumstances, not only can be interpreted as a refuge for

\footnotetext{
${ }^{6}$ In fact Levi introduces the novel If this is a Man with a petition to his readers: "Vi comando queste parole. / Scolpitele nel vostro cuore / Stando in casa andando per via, / Coricandovi alzandovi; / Ripetetele ai vostri figli.
}

survival, but also, intrinsically, as one of the ways to survive; i.e. when the process of reconstructing communications -both oral and written- begins, one starts to get out of chaos.

In the first novel, there are many scenes that reflect clearly how the prisoners in the camp, from virtually all nations of Europe and each of them with their own language [10], are trying to communicate with each other and their captors in a context with multiple and unknown linguistic codes: $L a$ confusione delle lingue è una componente fondamentale del modo di vivere di quaggiù; si è circondati da una perpetua Babele, in cui tutti urlano ordini e minacce in lingua mai prima udite, e guai a chi non afferra al volo (p. 44).On the contrary, the second novel introduces a condition of alterity, so that in addition to the "I", the "other" is included: that is why one of the main features of The Truce is the pressing need to understand each other. The linguistic codes are still multiple and unknown, but in a different communication context. There are plenty of scenes where we can see how those who had been released try to communicate in a strange land, Poland, and try to establish communicative relationships with all the vast gallery of characters who cross the pages of the novel. The need to talk, to establish human relationships through words, gestures and conversation predominates as one of the acts that characterize Man and stands as a way to return the dignity he had been stripped off.

In short, our aim is to delve into the mechanisms Levi uses in these two novels, to analyse the use of language/languages not only as a system of both physical and moral survival, but also as a reconstruction of the essence of the individual who, thanks to something as human as the ability to speak, is born again after having stayed in Auschwitz [11] ${ }^{7}$. In this way language can be interpreted as a linking element between what one was and returns to be by means of Words.

The use of language, i.e. the ability to speak or the denial of this same ability, the need for translation and interpreters, -as at the time of arrival at the camp, when the Germans screamed incomprehensible orders: qualcuno tradusse: bisognava scendere coi bagagli e depositare questi lungo il treno (p. 19)- is permanently present in both of the novels by Levi on which we will focus, although in different dimensions: in the first one the constant feature is non-communication -which helps the desire of the Nazis to convert the man into a non-human: Allora per la prima volta ci siamo accorti che la nostra lingua manca di parole per esprimere questa offesa, la demolizione di un uomo (p. 29)-, the near absence of communication and the difficulties to establish it: $i$ quattro parlano una lingua che non sembra di questo mondo (p. 25).

Conversely, in The Truce, as Cases says: "La babele continua, la vita è sempre dominata dal caos e dall'irrazionalità, ma di un altro tipo, dovuto alla disorganizzazione e non all'eccesso di organizzazione [...] La babele sotto il segno russo è quindi variopinta e

\footnotetext{
${ }^{7}$ Meghangi points out: "Anche il linguaggio del Lager è per lui una traccia da cui risalire, un punto di partenza per comprendere il sistema nella sua unicità"
} 
contraddittoria, ma tutto sommato inoffensiva e spesso allegra" [12]. Emphasis is placed, above all, on the desire to rebuild communication, on the need to re-communicate to recover part of what has been lost and, at the same time, to restore the human being. In other words, in this novel the non-human becomes a man again and, through the account of memories, he recovers his stolen dignity [13]. In the reconstruction of his identity, the urgency to restore communication links, -even to the extent of using Latin, if necessary: intavolando in latino la più stravagante ed arruffata delle conversazioni (p. 55)-, is a constant: albergavo in me fame vecchia e freddo, e inerzia, ed insieme curiosità, spensieratezza, e una nuova e saporita voglia di attaccare discorsi, di intavolare rapporti umani, di fare pompa e sprecco della mia smisurata libertà (p. 53).

It is well known that the ability to speak -i.e. talking to understand and be understood- was one of the reasons why Levi could survive his imprisonment in the camp. He succeeded, albeit with difficulty, in understanding what the Nazis were saying and so he could understand the orders. In one of the moments of his conversations with Camon, he says [14]:

Il motivo fondamentale era che mancava la comunicazione: e questo era il secondo trauma ${ }^{8}$. Pochi fra noi ebrei italiani capivano il tedesco o il polaco; pochissimi. Io sapevo qualche parola di tedesco. L'isolamento linguistico, in quelle condizioni, era mortale. Sono morti quasi tutti gli italiani per questo. Perché fin dai primi giorni non capivano gli ordini, e questo non era ammesso, non era tollerato. Non capivano gli ordini e non potevano dirlo, non potevano farsi capire. Sentivano un urlo, perché i tedeschi, i tedeschi militari, urlano sempre [...] Questo fatto era già un primo grosso ostacolo all'unione, al riconoscersi come compagni. Io -1 'ho sempre detto, sono stato fortunato- mi son trovato a possedere un minimo di lingua tedesca, l'avevo studiata come chimico, e ho potuto instaurare una certa comunicazione con i non-italiani: e questo era fondamentale per capire dove vivevo, il decalogo di quel luogo. E anche per percepire questo senso di unione di cui lei parla. Infatti ricordo che quando si stabilirono dei contatti con amici prigionieri francesi, ungheresi, greci, ci sembrava di esser saliti di un gradino.

But, at the same time, there is another way to survive, like the one they find out in The Truce: the will of understanding urged by dialogue, which encourages pacific relationships and helps the individual and a split society recover morally and ethically after a devastating war. To that extent, alterity is necessary in order to understand individual differences, because if there is a will of alterity, the need of integration can be more harmonious.

\footnotetext{
8 The first "trauma", always according to Levi, derived from the intangible fact that being born Jewish was the only reason for his intended extermination.
}

The contents of these two works are analysed in detail in the work which closes the Trilogy about Auschwitz, the essay The Drowned and the Saved, where Levi investigates about fundamental issues such as freedom, oblivion and engagement; in chapters 3-4 he speculates about "Shame" (following liberation from the camp many inmates had a shame sensation and feelings of guilt) and "Communicating" (about the impossibility of communications as another form of «useless violence»), which are issues of our particular interest.

\section{Discussion and Analysis}

\subsection{If This is a Man}

In If This is a Man Levi aims not only to describe the horrors of the extermination camp but also to tell his own interpretation of the moral and psychological conditioning that existed there. Hence the novel can be read primarily as a reflection of all attacks on the dignity of man, both physical and moral, and the explicit reduction of man into a thing, a beast. The process of brutalization of human beings, whose aim is the complete negation of the human entity, is realized through the annihilation of a feature that identifies and separates men from animals, i.e. their ability to communicate through words, which was one of the key elements that Levi was fully conscious of.

Today, no one can deny that the Nazi program aimed primarily to submit men and cancel their humanity, to turn them into beasts, things, numbers, to deprive them of their identity. Prisoners were not seen as human: Vorrei ancora accennare, come esempio estremo di violenza ad un tempo stupida e simbolica, all'empio uso che è stato fatto (non saltuariamente, ma con metodo) del corpo umano come di un oggetto, di una cosa di nessuno, di cui si poteva disporre in modo arbitrario (ISS p. 99). In the initiation process to submission they were stripped, shaved and dressed in rags; they were separated from their families and friends; all their personal items were removed, including photographs of their loved ones. In a word, their past was wiped out. And in this process of annihilation of the dignity, the most symbolic act was to cancel their proper names. The «initiation ceremony» in Auschwitz meant precisely the loss of the name and the award of a number like a license plate [15]. Their humanity was lost because they lost one of the elements that make up its essence: Ho imparato che io sono uno haftling. Il mio nome è 174 517; siamo stati battezzati, porteremo finché vivremo il marchio tatuato sul braccio sinistro ( p. 30).

But also, in this process it is obvious that eliminating the possibility of communication was one of the essential requirements. The fear of the unknown, of not knowing, of not being able to ask, the lack of reason for the things that happened there, the anguish due to communicative loneliness, i.e. the vuoto comunicativo (communication vacuum) as Levi calls it, the fact that they spoke to you and 
you did not know what you were told, that you wanted to talk but you were not understood were all causes for the biggest trauma for prisoners, for the haftlinger $[16]^{9}$.

Survival in the extermination camp required knowing a number of fundamental rules: not wasting bread crumbs -erected as a symbol of survival-, as they were the only currency of possible change and that is why Levi remembered the word "bread" in all the languages present in the camp: pane-Brot-Broit-chleb-pain-lechem-kenyér ( $\mathrm{p}$. 45) [17]; calculating one's position in the queue so that the bowl of soup would contain more than just liquid; sleeping with all belongings - spoon, plate and shoes - so that they were not stolen overnight; knowing the places permitted and those which were prohibited: nur für Kapos, nur für Reichsdeutsche (SQU: 38); not getting too close to the filo spinato (barbed wire) and many other practical things. But certainly, the most important and fundamental rule was to know and pronounce a word: rispondere "Jawohl" e non fare mai domande, fingere sempre di aver capito (SQU: 37).

Life runs in a rhythm dominated by two terms: Ausrücken and Einrücken, exit and return, terms that make up the cycle of life in the concentration camp: lavorare, dormire, mangiare; ammalarsi, guarire o morire (p. 41); they are preceded by another word that means the condemnation of every day: Aufstehen (in German) Wstawac (in Polish) about which Levi says: La parola straniera cade come una pietra sul fondo di tutti gli animi. "Alzarsi" (p. 78).

If language is what makes us human, knowing the words of the concentration camp helps knowing better the conditions of the place. In this regard, it should be noted that the written form reflects linguistic situations that emphasize the author's memorial use of language when he chooses among the terms in German -sometimes in Polish - in If This is a Man, terms for which he provides translation ${ }^{10}$. One of the first forms of cultural domination is the obligation to use new and unknown words and expressions in a foreign language to express known reality, as stated by the Hungarian writer Imre Kertész, literature Nobel Prize [18].

In this novel Levi uses German when he refers to the various professions of the commanders in the camp such as Tagesraum (capo-baracca), Blockfrisör (barbiere autorizzato), Arbeitsdienst (assegnazione dei singoli ai vari Komandos), Scheissbegleiter (accompagnatore alle latrine).

He also uses German for the names of the different Blocks, like when he describes the distribution of the camp: Di più, alcuni Blocks sono adibiti a scopi particolari. [...] v'è poi il Block 24 che è il Krätzeblock, riservato agli scabbiosi; il

\footnotetext{
9 In this sense, it is a curious dream that Levi has in the camp, outlined in the conversation with Camon and recalled in the pages of The Truce: "Sognavo che tornavo, rientravo nella mia famiglia, raccontavo e non ero ascoltato. Colui che mi stà davanti no mi stà a sentire, si volta e se ne va". But even more surprising is that: "Ho raccontato questo sogno, in Lager, ai miei amici, e loro hanno detto: Capita anche a noi"

${ }_{10}$ Language that, for obvious reasons, is almost absent in the novel The Truce in which the "other language" was Russian, because the soldiers who liberated the camp were Russians, or Polish, because Poland is where the plot takes place.
}

Block 7, in cui nessun comune Häftling è mai entrato, riservato alla "Prominenz" [..] il Block 47, riservato ai Reichsdeutsche (gli ariani tedeschi, politici o criminali); il Block 49, per soli Kapos; il Block 12, una metà del quale ad uso del Reichsdeutsche e Kapos, funge da Kantine [...] e infine il Block 29, che ha finestre sempre chiuse perché è il Frauenblock, il prostibolo del campo, servito da ragazze Häftlinge polacche, e riservato ai Reichsdeutsche (p. 36).

German is used-sometimes also Polish- to refer to the many signs of prohibition and the various orders that were given: Wassertrinken verboten (vietato bere), So bist du rein (così sei pulito), So ghest du ein (così vai in rovina), Eine Laus, dein Tod (Un pidocchio è la tua morte), Nur für Polen, Nur für Ukrainische Franen, Nur für Hätflinge; or also to make a list of the various diseases of the prisoners: dicke Füsse (piedi gonfi), Körperschwäche (deperimento organico). And also to refer to the hard work of Buna, where the bricks, $i$ mattoni, are the symbol of slavery -just as bread of survival-, and this is why he refers to them using the different languages of the camp: I suoi mattoni sono stati chiamati Ziegel, briques, tegula, cegli, kamenny, bricks, téglak, e l'odio li ha cementati; l'odio e la discordia, come la Torre di Babele, e così noi la chiamamo: Babelturm, Bobelturm (p. 90).

This language, these terms and expressions are necessary to survive in Auschwitz and they play an evocative role. That is why they are recalled in the exact way the protagonist heard and pronounced them. But in particular they certainly connote a whole jargon of violence and intolerance, a mutation of the German language -a degradation, in Levi's own words- which create a kind of koiné, of jargon of all Lagers: Non mi rendevo conto, e me ne resi conto solo molto più tardi, che il tedesco del Lager era una lingua a sé stante: per dirla appunto in tedesco, era orts-und zeitgebunden, legata al luogo ed al tempo. Era una variante imbarbarita, di quella che un filologo ebreo tedesco, Klemperer, aveva battezzata Lingua Tertii Imperii, la lingua del Terzo Reich, proponendone anzi l'acrostico LTI in analogia ironica con $i$ cento altri (NSDAP, SS, SA, SD, KZ, RKPA, WVHA, RSHA, $B D M . .$. ) cari alla Germania di allora (ISS, p. 76).

Language was used with the clear intention of maintaining the dominating ideology; forcing the prisoners to learn and use it was for the Nazis a way to wipe out the individuals' personality in order to transform them in a shapeless mass to be commanded by the hierarchy [19]. Levi, by using German words as they are recalled in his memory, is willing to witness that he was so submitted that, on one occasion, after having passed the chemistry examination to became a specialist, so as to be able to leave the hard work of Buna, he concludes: Io brancolo per un attimo nella ricerca di una formula di congedo appropriata: invano, in tedesco so dire mangiare, lavorare, rubare, morire; so anche dire acido solforico, pressione atmosferica e generatore di onde corte, ma non so proprio come si può salutare una persona di riguardo (p. 136).

Beyond that jargon covering the violence and intolerance 
of the concentration camp, the use of the German language has a softer side as well, because it is also a language that allowed the prisoners to survive. By means of German, although badly spoken and sometimes more gestured than pronounced, the protagonist can talk to some of the prisoners in the camp, such as the Polish Jew Schlomer, the blacksmith. When Levi narrates the meeting with Schlomer in the infirmary, the written text perfectly reflects the pastiche used in spoken language: -Ich Chemiker,-dichiaro io [...] Chemiker gut [...] Bere, acqua. Noi niente acqua-gli dico. Non bere acqua, compagno. E poi altre parole che non capisco [...] Warten bis heute aben-Aspettare fino oggi sera, traduco io parola per parola (p. 34-35).

The urgency and the need for communication with other prisoners in the camp is a constant trait in the narrative. Perhaps, one of the most emotional scenes of the whole novel is the conversation, half-French, half-Italian, half-German, with Jean in the chapter "Il canto di Ulisse" in which Dante and his Divine Comedy appear as a sign of freedom and of normalcy amid the desolation. In this sense, the writers that survived concentration camps - such as Jean Améry [20]- share the idea that the prisoners who were "men of spirits" suffered even more when realising that all the personal culture and knowledge was annihilated in that context of cruelty.

In conclusion, surviving physically and emotionally involves not only understanding how to live in the concentration camp, but also communicating - in its pragmatic sense - to feel that one is part of a world that still exists. And in this particular world, based on the need for communication, hatred is overcome by the desire for everyday life, even using a language such as the one that identifies with the rulers ${ }^{11}$.

\subsection{The Truce}

The first chapters of The Truce deal with the memories of the last days in the Lager, after the arrival of the Russians who liberated the camp. In the novel there is a new setting: Auschwitz Poland is now a country of liberated people. Life conditions are diametrically opposed so that the other narrative elements change as well. German words are no longer needed as German is no longer the language of submission by a dominating hierarchy.

Russian and Polish replace German as a Koiné language. Overall, the relationship of the protagonist with this new life situation, and in general with the new context, is more

\footnotetext{
${ }^{11}$ It is interesting to point out that the Nazis imposed strict language rules forbidding the use of certain words and expressions such as "extermination", which were to be replaced by euphemisms such as "final solution". Levi remembers it in the first chapter of the The Drowned and the Saved: "I ben noti eufemismi («soluzione finale», «trattamento speciale», lo stesso termine «Einsatzkommando» appena citato, che significa letteralmente «Unità di pronto impiego», ma mascherava una realtà spaventosa) non servivano solo ad illudere le vittime ed a prevenirne le reazioni di difesa: valevano anche, nei limiti del possibile, ad impedire che l'opinione pubblica, e gli stessi reparti delle forze armate non direttamente implicati, venissero a conoscenza di quanto stava accadendo in tutti i territori occupati dal Terzo Reich" (p. 17).
}

positive and this is reflected in the written text. There are no more foreign words as there is no more dominating language ${ }^{12}$.

One of the distinctive elements of this novel is the reconstruction process of the protagonist and the characters surrounding him, all of them liberated from the Auschwitz Camp. And this process is shaped also by the use of language.

Levi no longer identifies the new communicative situation with a dominant language but with a language that is identified with the process of liberation. In the infirmary of Katowice, one of the places in Poland where much of the action of this novel takes place, Levi points out that: sullo spazio centrale del campo si era quindi svolta una sorta di versione caricaturale delle selezioni tedesche. Una versione assai meno sanguinosa, poiché si trattava di andare al lavoro e non alla morte [...] Il giudizio se "bolnoj" o "zdorovyj" (ammalato o sano) veniva pronunziato collegialmente, per acclamazione, non senza dispute rumorose nei casi controversi (p. 84).

The episode in which the protagonist -working as a pharmacist-polyglot and assistant to Marja- tells how patients in the hospital were registered, could be defined somehow weird: in che lingua tenere la registrazione? Non in italiano né in francese né in tedesco, che né Marja ne Dancenko conoscevano. In russo allora? No, il russo non lo conoscevo io [...] Gallina avrebbe risolto la situazione [...] conosceva il tedesco. Cosi avrei potuto dettarle $i$ verbali in tedesco, e lei li avrebbe tradotti in russo seduta stante. [...] ad ogni scoglio lessicale eravamo costretti ad arrestarci in preda al dubbio, e a ricorrere a complicate gesticolazioni, che finivano in squillanti risate da parte di Gallina (p.73). And the episode of the inspection of the camp by a Russian general is a kind of parody: L'interprete di Rovi galoppava di camerata in camerata, vociferando ordini e contrordini (p. 86).

These episodes show the start of the reconstruction process where The Truce mirrors If This is a Man: the facts that in Auschwitz could have meant death, are now some kind of painless memories, told as mere anecdotes in an antithetical comedy tone.

In this novel Levi uses the alterity process because the presence of the group helps the reconstruction of individuality. Only through the eyes of the others it is possible to recognise a new world [21]. In this new context the choral element, mainly from the point of view of linguistic communication, is a new resource: it is practically absent in the first novel where the struggle for survival was individual.

Spoken or written words and the communication process between a transmitter and a receiver play an important role

\footnotetext{
12 The need for interpreters and their presence- is a constant in The Truce. Before leaving the Concentration Camp he mentioned Yankel: un giovane ebreo russo fra $\mathrm{i}$ superstiti, ed in quanto tale si era trovato naturalmente a rivestire la funzione di interprete e di ufficiale di collegamento coi comandi sovietici (p. 15).
} 
again because both speakers share the same code in a new favourable referential context. Indeed, one of the fundamental factors of the communication process is the context, i.e. time, space, facts and social cultural circumstances that can affect the transmitter and receiver in their process of comprehension of the message.

Levi wants his reader to become aware of the fact that the context has changed, that is why his writing is enriched with new situations. In this renovated context primary feelings friendship or compassion- and concepts such as solidarity find their place again and are fundamental for the «nonman» to become a man.

The author selects in his memories different facts and characters that arouse in the protagonist / writer feelings of compassion and solidarity, thanks to the presence of alterity. One is the case of little Hurbinek, one of the last to die in the concentration camp after liberation. Hurbinek is the first icon representing the return to the humanity that had been stripped off: Nei giorni seguenti, tutti lo ascoltavamo in silenzio, ansiosi di capire, e c'erano fra noi parlatori di tutte le lingue d'Europa: ma la parola di Hurbinek rimase segreta. No, non era certo un mesaggio, non una rivelazione: forse era il suo nome, se pure ne aveva uno in sorte; forse (secondo una delle nostre ipotesi) voleva dire "mangiare", o "pane"; o forse "carne" in boemo, come sosteneva con buoni argomenti uno di noi, che conosceva questa lingua (p.29).

The case of Ferrari is also symbolic. Ferrari, a common criminal arrested in Italy in 1944 and then sent to Auschwitz, had got used to loneliness. Levi mentions him to underline that, despite being an illiterate, he is a tireless reader because reading is his way to feel a free man again: Leggeva tutto quanto gli capitava sotto mano: giornali e libri italiani, francesi, tedeschi, polacchi [...] Non era già un poliglota: anzi, era praticamente analfabeta. Ma "leggeva" ugualmente ogni libro, dal primo rigo all'ultimo, identificando con soddisfazione le singole lettere, pronunciandole a fior di labbra, e riscostruendo faticosamente le parole, del cui significato non si curava (p. 77).

Only through the awareness of the new context can the reader understand Daniele's gesture. He shares his bread, his only possession, with the other miserable prisoners in a Europe devastated by war, even if they are soldiers dressed in uniforms of the Wehrmacht. This scene is a reflection of the reconstruction al rovescio (reverse reconstruction), it is an antithetical counterpoint which links and separates at the same time If This is a Man and The Truce: Ci chiesero pane: non nella loro lingua, bensì in russo. Rifiutammo, poiché il nostro pane era prezioso. Ma Daniele non rifiutò: Daniele, a cui $i$ tedeschi avevano spento la moglie forte, il fratello, $i$ genitori, e non meno di trenta parenti; Daniele, che della razzia nel ghetto di Venezia era il solo superstite, e che dal giorno della liberazione si nutriva di dolore, trasse un pane, e lo mostrò a quelle larve, e lo depose a terra (p. 142).

No less important in the characters' recovery of morals and ethics are the events that the protagonist lives with his friend Cesare, a survivor by nature, a rogue in a destroyed world, a ciarlatano (a charlatan) who, thanks to his eloquence, was able to fight to stay alive: accettai di buon grado l'invito di Cesare ad accompagnarlo qualche volta al mercato, como apprendista, interprete e portatore. Lo accettai, non solo per amicizia, e per fuggire la noia del campo, ma soprattutto perché assistere alle imprese di Cesare, anche alle più modeste e triviali, costituiva una esperienza unica, uno spettacolo vivo e corroborante che mi riconciliava col mondo, e riaccendeva in me la gioia di vivere che Auschwitz aveva spenta (p. 93).

Near the end of the novel, on the way back to Italy -a journey that has been interpreted as an allegory of vital reconstruction- the protagonist says that the chain of his memories is fragmented in two phases, amputated by his imprisonment in Auschwitz. His memories stop at the railway and are recovered only after forever leaving the hell surrounded by the filo spinato (barbed wire). Only then can he recover the memories of the hell narrated in If this is a Man and put them into order after the vital reconstruction narrated in The Truce.

In this way no one can deny or forget what happened. Levi feels the moral obligation to remember those who survived but are not able to tell their experiences - such as Ferrari- and also those who died -such as little Hurbinek-. In some way, Levi offers us his writing in the name of the others, as a payback of a debit made by the survivors who witnessed the facts. Memory becomes salvation against oblivion.

\subsection{The Drowned and the Saved}

With the publication of The Drowned and the Saved, the trilogy of Auschwitz is completed. We mustn't forget, as we read in one of the signs that welcome visitors to Auschwitz, 'The one who does not remember history is bound to live through it again'. Indeed, all the memories that Levi narrates in the novels, are the subject matter of his reflection in The Drowned and the Saved.

Whit this essay, the final result of his experiences, readings, lectures and interviews as a survivor of Auschwitz, Levi wants to shape the readers' opinion about the psychological and sociological conditioning that the Holocaust implied. The work describes with lucidity and distance the psychological mechanisms which underlie the phenomenon of concentration camps as places of physical and moral systematic destruction of human beings [22].

In the chapter entitled "Comunicare" (Communicating) Levi points out that in the world of Auschwitz, not only was there "Incomunicabilità" (incommunicability); rather, there was a total language barrier where those who did not understand knew that their lives depended on understanding: Il sapere o no il tedesco era uno spartiacque (p. 70). All human beings are biologically and socially prepared to establish communication: ed in specie per quella sua forma altamente evoluta e nobile che è il linguaggio (p. 69). But this essential condition was lacking in the Concentration Camp where non-communication reigned. In the Lager, 
those who understood German established something like a human relationship; but those who couldn't were treated like beasts: i neri reagivano in un modo che ci stupi e spaventò. $L$ 'ordine, che era stato pronunciato con la voce tranquilla di chi sa che verrà obbedito, veniva ripetuto identico con voce alta e rabbiosa, poi urlato a squarciagola, come si farebbe con un sordo, o meglio con un animale domestico, più sensibile al tono che al contenuto del messaggio (p. 70).

When the context changes -as we stated before- the linguistic code changes as well. If Man undergoes an animalization process, the language used is that of mistreated animals, with shouts and blows. When shouts were not understood blows started: l'unico linguaggio che in quella perpetua Babele potesse veramente essere inteso da tutti (p. 56).

The fundamental function of language, i.e. the transmission of a thought though a linguistic code shared by the transmitter and the receiver, was unexisting in Auschwitz: "Se qualchuno esitava (esitavano tutti, perché non capivano ed erano terrorizzati) arrivavano $i$ colpi, ed era evidente che si trattava di una variante dello stesso linguaggio: l'uso della parola per comunicare il pensiero, questo meccanismo necessario e sufficiente affinché l'uomo sia uomo, era caduto in disuso (p.72). And this was a clear sign that there, in the concentration camp, there were only «nonmen») (especially Jews). There were only animals, like horses, recalls Levi, who obey because they are given a blow or because they are shouted at. When German was not well understood and there was no chance of finding someone to talk to, to understand you or for you to understand: la lingua ti si secca in pochi giorni, e con la lingua il pensiero (p. 72).

Levi in this work insists on the need of the survivors to tell all their past experiences; but at the same time they felt the need to be understood by the others. In this way memories had to find a double communication path between the transmitter (the survivors of Auschwitz) and the receiver (mankind). As a survivor, chosen to live instead of dying without any logical reason, writing becomes the way to give sense to the existence of all those who died, the way to listen to the voices of those who were shut up.

During the return trip, when the train briefly passed through Germany, Primo Levi said: Ci sembrava di avere qualcosa da dire, enormi cose da dire, ad ogni singolo tedesco, e che ogni tedesco avesse da dirne a noi: sentivamo l'urgenza di tirare le somme, di domandare, spiegare e commentare, come i giocatori di scacchi al termine della partita. Sapevano "loro", di Auschwitz, della strage silenziosa e quotidiana, a un passo dalle loro porte? Se sí, come potevano andare per via, tornare a casa e guardare $i$ loro figli, varcare le soglie di una chiesa? Se no, dovevano, dovevano sacramente, udire, imparare da noi, da me, tutto e subito: sentivo il numero tatuato sul braccio stridere come una piaga (LT, p. 251).

In this alterity process the verb capire (understand) acquires a polysemic function in the three works: understanding the language, but also understanding the rules of the concentration camp, both being ways to survive. In this process of understanding for the survivors of the camps, Levi includes both those who were responsible for the massacre and those who, from outside of the camps, knew and were silent: capire also meant, for all of them, to take the blame. The "blame" for being born Jew -the only reason for their extermination- meets the "shame" for having survived the others.

Levi stops particularly in the analysis of these reflections in the chapter "La vergogna" (Shame). On the one hand, after liberation, shame, or a feeling of uneasiness similar to it, is identified with a senso di colpa of many of the prisoners in the camp, mostly Jewish prisoners. Shame and guilt derive basically from the fact of having consented to destruction, of not fighting, of surrendering: Avevamo sopportato la sporicizia, la promiscuità e la destruzione [...] perché il nostro metro morale era mutato. Inoltre, tutti avevamo rubato [...]; alcuni (pochi) erano discesi fino a rubare il pane al proprio compagno (p. 57). Especially after liberation, the awareness of having done nothing - or not enough- emerged strongly together with the need for justifying or seeking a barrier behind which defending oneself.

But guilt is also derived from the omission of help, a constant in the life of the Concentration Camp, where the main slogan for survival was "take care of yourself": $L a$ richiesta di solidarietà, di una parola umana, di un consiglio, anche solo di un ascolto, era permanente e universale, ma veniva soddisfatta di rado (p. 60). Shame for having lived instead of another - perhaps someone more generous, more sensitive, more intelligent, more useful-, is a feeling devouring you and it was deeply rooted in those who survived the death camps like Auschwitz; in fact, the feeling was that those who had survived were not the best, but those who could best adapt themselves to the new context.

From this point of view, words and writing can be interpreted as a therapy to survive this sense of guilt, as a reconciliation mechanism that can give sense to suffering.

Finally, Levi reminds us that there is a larger and wider shame, the shame of the world, of all those who, before the faults of others or before their own faults, turned their backs nell'illusione che il non vedere fosse un non sapere, e che il non sapere li alleviasse dalla loro quota di complicità o di connivenza ( $\mathrm{p}$. 66); this is a shame so difficult to cope with, the understanding of which is based on realizing that the human being has been capable of building a great amount of sorrow: una mole infinita di dolore; e che il dolore è la sola forza che si crei dal nulla, senza spesa e senza fatica. Basta non vedere, non ascoltare, non fare (p. 67).

\section{Conclusions}

During his exile due to the Nazis, Thomas Mann said that the homeland of a writer was his language. Like him, many other writers and essayists - Elie Wiesel, George Steiner, Elias Canetti, Jorge Semprún, Aharon Appelfedl, Jean Améry or Levi himself - were conscious of the importance of language in witnessing and analysing the horrors of 
Concentration Camps, that several of them interpreted as a synecdoche of «genocide». Words could give evidence of what happened in Europe in the first half of the 20th century through testimonial narration and essay, two genres Levi uses to tell and put order in his personal chaos, which is an allegory of the one that Europe lived in the years immediately following the end of the war.

In his testimonial writing as well as in his analysis, Levi follows a principle: if language is the characteristic of the human species, language leads to a better understanding of the human nature.

On one hand, the text, which is a testimony of what happened, enables the survivors to narrate the facts of the vanquished. From this standpoint, through narration, language and words, past and present can be connected and memories kept alive; they are the means by which memory can be preserved despite the passing of time, which leads to oblivion.

On the other hand, language and words, as a communication act, contribute to the survival of the prisoners and to keep the hope of escape alive, because language and words connect the vanquished man with what he once was and that he recognizes as something that belongs to him.

In the world narrated by our author, communicating with each other, understanding each other, understanding the Decalogue of the camp and, above all, knowing languages, getting acquainted with that linguistic Babel, opened a door for physical and moral survival.

In the three texts Primo Levi particularly insists on the mechanisms of the communication process which transcends the use of language: the modification of the context implies the modification of conventional signs and signals, that constitute a new code to be necessarily identified. In the first novel, If this is a Man, deciphering the keys of this new code is vital in order to survive because the transmitter and the receiver do not share the same code. The pragmatic situation changes and, as a consequence of this, the logic relation between "emitting" and "understanding" is altered. The title of the work itself gives a hint as to what Levi wants to relate. The syntactic construction, enouncing the protasis of a conditional clause but leaving out the apodosis, leaves the sentence suspended and can as well be interpreted as a question without an answer.

This situation, thanks to the fact that the context has changed, starts its return movement in The Truce. Through an equally significant title, Levi begins writing the apodosis, the second part, so as to get out of the suspension. The pragmatic context has changed - despite the linguistic difficulties - and man undergoes a process of reconstruction back to his human identity. Socializing with others through language restores dignity, after that what is intrinsically human has been stolen, i.e. the possibility of a relationship with others through words and communication.

Primo Levi wants to show us, and so he does in The Drowned and the Saved, that the problem was not only the lack of linguistic communication but also the fact that in a context of barbarism no kind of communication is possible because man, who is able to use written and spoken words, is no longer a man. That is why Levi says that the survivors (the Saved) needed to analyse the keys that enabled them to decipher the codes of the Concentration Camps. One of such keys was understanding through individual and collective guilt so as to give voice to the Drowned: Nella maggior parte dei casi, l'ora della liberazione non è stata lieta né spensierata [...] Che molti (ed io stesso) abbiamo provato "vergogna", e cioè senso di colpa, duante la prigionia e dopo, è un fatto accertato e confermato da numerose testimonianze (p. 52).

Today language conflicts are part of common news media, as a direct result of political disputes based on nationalist positions that make use of language as if it were a major flag to claim a difference. Primo Levi, in these three stories, gives us a warning: when the ability to communicate is taken away, other freedoms are also denied. When discussion dies, the opinions imposed prevail and ignorance and intolerance grow based on the ideology of only the few.

That is how powerful language can be. And Levi has given us a good testimony of it: Abbiamo avuto modo di capire bene, allora, che del grande continente della libertà la libertà di comunicare è una provincia importante (p. 81).

* Masculine gender is used throughout this document solely for purposes of clarity and readability, and by no means with the intent to discriminate. It refers to both men and women.

\section{REFERENCES}

[1] Primo Levi, Se questo è un uomo, Torino, Einaudi, 1976 If This is a Man and The Truce, Translated by Stuart Woolf. With an Introduction by Paul Bailey and an Afterword by the author, London, Abacus, 2004.

[2] David Meghangi, "La vicenda ebraica. Primo Levi e la scrittura", Primo Levi. Un'antologia della critica, (a cura di E. Ferrero), Torino, Einaudi, 1997, 289-299: 292. Vanna Zaccaro, Dire l'indicibile. Primo Levi fra testimonianza e racconto, Lecce, Pensa multimedia, 2002.

[3] Anna Bravo, Danielle Jalla (a cura di), Storia e memoria dei Lager nazisti nei racconti di duecento sopravvissuti, Milano, Franco Agneli, 1986.

[4] Primo Levi, La Tregua, Torino, Einuadi, 1997. If This is a Man and The Truce [op.cit.1].

[5] Angela Flury, "Discovering 'Europe' in the Process of Repatriation: Primo Levi's La Tregua", in The Idea of Europe in Literature, (ed. by Susanne Fendler and Ruth Wittlinger), Basingstoke- London, Macmillan - New York, St. Martin's Press, 1999, 64-82.

[6] About Levi's life: Marco Belpoliti, Primo Levi, Milano, Mondadori, 1998; Ernesto Ferrero. Primo Levi: La vita, le 
opere, Torino, Einaudi, 2007; Sophie Nezri-Dufour, Primo Levi: una memoria ebraica del Novecento, Firenze, Giuntina, 2002.

[7] Primo Levi, I sommersi e i salvati, Torino, Einaudi, 2007. The Drowned and the Saved, Translated by Raymond Rosenthal. Introduction by Paul Bailey, London, Abacus, 2013.

[8] Marco Belpoliti (a cura di), Primo Levi. Conversazioni e interviste 1963-1987, Milano, Marcos \& Marcos, 1997; Ferdinando Camon. Conversazione con Primo Levi, Milano, Garzanti, 1991; Gabriella Poli - Giorgio Calcagno, Echi di una voce perduta: incontri, interviste e conversazioni con Primo Levi, Milano, Mursia, 2007.

[9] Enrico Mattioda, L'ordine del mondo. Saggio su Primo Levi, Napoli, Liguori, 1998: 3. About Levi's chaos theory: Cesare Cases, "Introduzione. L'ordine delle cose e l'ordine delle parole", in Primo Levi, Opere, I, Torino, Einaudi, 1987, IXXXXI; Giovanni Tesio, "Primo Levi tra ordine e caos", in Primo Levi as Witness: Proceedings of a Symposium held at Princeton University, April 30 - May 2, 1989, (a cura di Pietro Frassica), Firenze, Casalini, 1990, 108-128.

[10] Jorge Larrosa, Entre las lenguas. Lenguaje y educación después de Babel, Barcelona, Ediciones Laertes, 2003; Cesare Segre, "Primo Levi nella Torre di Babele", in Primo Levi as Witness (op. cit.), 86-97; George Steiner, After Babel: aspects of language and translation, London, Oxford, 1976; id. Lenguaje y silencio, Barcelona, Gedisa, 1994.

[11] David Meghangi [op. cit. 2]: 292.

\section{[12] Cesare Cases [op. cit. 9]: XXVI / XXVII}

[13] For an overview on Memory in Levi: Primo Levi: memoria e invenzione, Atti del convegno internazionale, San Salvatore Monferrato, 26-27-28 settembre 1991,(a cura di Giovanna Ioli), San Salvatore Monferrato, Edizioni della Biennale "Piemonte e Letteratura", 1995; Mario Barenghi, "La memoria dell'offesa. Ricordare, raccontare, comprendere", in Al di quà del bene e del male: la visione del mondo di Primo Levi, Atti del Convegno internazionale, Torino, 15-16 dicembre 1999, (a cura di Enrico Mattioda), Milano, Angeli, 2000; Sophie Nezri-Dufour, Primo Levi: una memoria ebraica del Novecento [op.cit.6]; Alexander Stille, "Primo Levi and the art of memory", in Primo Levi as Witness [op. cit. 9], 98-107.

[14] Ferdinando Camon, [op. cit. 8]: 31.
[15] Esther Cohen, El silencio del nombre. Interpretación y pensamiento judio, Barcelona. Antrophos, 1999.

[16] Ferdinando Camon, [op. cit. 8]: 50.

[17] Gian Paolo Biasin, "Our Daily Bread-Pane-Brot-Broid-Chleb -Pain-Lechem-Kenyér”, in Primo Levi as Witness [op. cit. 9], $1-20$.

[18] Imre Kertész, A gondolatnyi csend, amíg a kivégzőosztag újratölt, 1998; trad. Un instante de silencio en el paredón. El Holocausto como cultura, Barcelona, Herder, 2002.

[19] Victor Klemperer, LTI. La lengua del Tercer Reich. Apuntes de un Filólogo, Barcelona, Minúscula, 2001: 24.

[20] Jean Améry, Beyond guilt and atonement (1964). Trad. Más allá de la culpa y la expiación, Valencia, Pre-textos, 2004.

[21] For further information on Alterity trends: Franco Catalani, "El mal en la dialéctica de la alteridad", Anclajes, VII, 7, (2003), 77-106; Jacques Derrida, De la gramatologie, Paris, Les éditions de minuit, 1967; id. L'écriture et la différence, Paris, Éditions du Seuil, 1967; James Jameson - Slavoj Zizek, Estudios culturales. Reflexiones sobre el multiculturalismo, Barcelona, Paidós Ibérica, 1999; Joan Carles Mèlich, La ausencia del testimonio: ética y pedagogía en los relatos del Holocausto, Barcelona, Anthropos, 2001; Patricio Peñalver Gómez, Argumento de alteridad. La hipérbole metafisica de Emmanuel Lévinas, Madrid, Caparrós, 2000; Ramón Pérez Martínez, Poder y Alteridad, Vigo, Academia del Hispanismo, 2013; Andrés Simón Losada, La experiencia de la alteridad en la fenomenología transcendental, Madrid, Caparrós, 2001.

[22] To deepen on Auschwitz, concentration camps and its survivors, see: Aharon Appelfeld, Tzili, la historia de una vida, Barcelona, Península, 2005; id. Vía férrea, Madrid, Losada, 2005; Walter Benjamin, Para una crítica de la violencia y otros ensayos, Madrid, Taurus, 1988; Víctor Klemperer, Quiero dar testimonio hasta el final: Diarios 1933-1941/ 1942-1945, Barcelona, Galaxia Guttemberg, 2003; Marcel Reich-Ranicki, Mi vida, Barcelona, Galaxia Guttemberg, 2000; Manuel Reyes-Mate Rupérez, La razón de los vencidos, Barcelona, Anthropos, 1991; id. Memoria en Occidente, Barcelona, Anthropos, 1997; id. Auschwitz. Actualidad moral y política, Madrid, Trotta, 2003; id. La herencia del olvido, Madrid, Errata Naturae editores, 2008; Elie Wiesel, Trilogía de la noche: la noche, el alba, el día, Grupo Planeta - El Aleph-, 2008. 